\title{
Research on a Compound Dual Innovation Capability Model of Intelligent Manufacturing Enterprises
}

\author{
Shan $\mathrm{Wu}^{1,2}$ and Jinlong Zhang ${ }^{1, *}$ \\ 1 Centre for Modern Information Management, School of Management, Huazhong University of Science and \\ Technology, Wuhan 430074, China; hairny@163.com \\ 2 Mathematical Modeling Research Centre, Wuhan Technology and Business University, Wuhan 430065, China \\ * Correspondence: jlzhang@hust.edu.cn
}

Citation: Wu, S.; Zhang, J. Research on a Compound Dual Innovation Capability Model of Intelligent Manufacturing Enterprises. Sustainability 2021, 13, 12521. https://doi.org/10.3390/su132212521

Academic Editor: Antonella Petrillo

Received: 9 October 2021

Accepted: 8 November 2021

Published: 12 November 2021

Publisher's Note: MDPI stays neutral with regard to jurisdictional claims in published maps and institutional affiliations.

Copyright: (C) 2021 by the authors Licensee MDPI, Basel, Switzerland. This article is an open access article distributed under the terms and conditions of the Creative Commons Attribution (CC BY) license (https:// creativecommons.org/licenses/by/ $4.0 /)$.

\begin{abstract}
The innovation capability of enterprises is reflected in whether their products and services can meet the needs of customers and adapt to the market. After analyzing the main differences between traditional manufacturing enterprises and intelligent manufacturing enterprises, it is proposed that intelligent manufacturing enterprises share the main characteristics of digitization, automation, platformization and flat manufacturing. Based on the theory of "ambidextrous innovation", this paper analyzes the mechanism of the innovation capability of intelligent manufacturing enterprises and notes that informatization and intellectualization are the driving forces between the innovation capability of enterprises. In addition, a "dual drive" and "ambidextrous innovation" have a direct effect on manufacturing and management, promoting products and services and comprehensively improving the quality of such products and services to enhance the core competitiveness of intelligent manufacturing enterprises. A compound dual innovation capability model for intelligent manufacturing enterprises is constructed, and the evaluation indices of the model are provided for reference. The present work provides research focuses and a theoretical framework for follow-up research on the innovation capability of intelligent manufacturing enterprises to promote the innovation and development of intelligent manufacturing enterprises.
\end{abstract}

Keywords: intelligent manufacturing; enterprise characteristics; ambidextrous innovation; innovation capability model; evaluating indicator

\section{Introduction}

With the rapid development and in-depth application of information network technology, IOT, big data, AI, cloud computing, mobile Internet, 5G, and other new generations of emerging information technologies are rapidly penetrating into different areas of the economy and society, and human society is accelerating into the era of digital economy. Deeper integration of the digital economy with the real economy, value creation, and optimal allocation of resources have given new impetus to high-quality economic and social development. This economic pattern is having a profound impact on the behavior of human society. It has spawned new modes of production, new economic organizations, new forms of business, and new business models, and has become an important driving force for the transformation and upgrading of enterprises and industries.

As an important pillar of the national economy, the manufacturing industry promotes the rapid and high-quality development of society, is the main source of industrial innovation and improves people's lives. However, international trade friction, the continuous development and application of new technologies, and the continuously increasing cost of factors of production have gradually lessened the advantages of traditional manufacturing [1,2]. The fourth industrial revolution has swept the world and promoted the transformation and upgrading of traditional manufacturing into intelligent manufacturing [3-5].

In recent years, China has issued a series of programmatic documents and guiding policies, including "Made in China 2025", "Integrated Development Plan of Informati- 
zation and Industrialization" and "Guidance on Developing the Internet and Advanced Manufacturing to Develop the Industrial Internet". These efforts indicate the country's goals of transformation from traditional manufacturing enterprises to intelligent manufacturing enterprises, which is of great significance to the reconstruction of the value creation system of the manufacturing industry and guidance on the innovative development of the manufacturing industry [6-8].

Intelligent judgment and decision-making must rely on high-quality information inputs and data-driven decision models. However, traditional manufacturing enterprises do not pay enough attention to information and data expressing information. Therefore, most of these firms' decisions rely on human experience, leaving the entire manufacturing system weak in response to external changes, low levels of efficiency, and insufficient innovation capability [9].

Ambidextrous innovation refers to the combination and coexistence of two kinds of innovation activities that conflict with each other. Scholars at home and abroad have carried out a series of studies on ambidextrous innovation of enterprises and found that exploratory innovation and exploitative innovation are effective ways to improve dynamic capabilities of enterprises in unstable social environment [10]. When studying the interaction between exploratory innovation and exploitative innovation, it is found that there is a potential nonlinear relationship between them and new product performance [11,12]. Further research finds that exploitative innovation may be effective in the short term, but may be harmful to enterprises in the long term [13]. Existing researches mainly focus on the interaction between ambidextrous innovation and its impact on firm performance, but ignore the analysis of the driving force of dual innovation.

This research is based on the investigation of 36 manufacturing enterprises in Shanghai, Wuxi, Wuhan, Zhengzhou and other places. During this research, 89 people were interviewed, including general managers, production supervisors, technical supervisors and so on. A total of $6319 \mathrm{~min}$ of interview recordings were obtained. Through these interviews, a deeper understanding of the management, production, and innovation process of manufacturing enterprises was obtained.

Based on the preliminary investigation, supported by the "Ambidextrous innovation" theory [14-16] and combined with the analysis of the characteristics of intelligent manufacturing enterprises, the connotation definition of the innovation capability of intelligent manufacturing enterprises is defined [17,18], and its driving force is analyzed. This study considers that the driving force of the innovation capability of intelligent manufacturing enterprises comes from informatization and intellectualization [19]. The innovation capabilities of intelligent manufacturing enterprises are understood as those capabilities based on the "dual drive" for informatization and intelligence $[20,21]$. The mechanisms of the innovation abilities of aintelligent manufacturing enterprises are also analyzed, and a "compound dual innovation capability model" of intelligent manufacturing enterprises is constructed. The construction of this model provides a theoretical framework for improving the innovation capability of intelligent manufacturing enterprises in China and plays an important role in promoting the innovation and development of intelligent manufacturing enterprises in China.

\section{Characteristics Analysis of Intelligent Manufacturing Enterprises}

Since the State Council issued "Made in China 2025" in March 2015 and established intelligent manufacturing as the main focus of the manufacturing industry, domestic scholars have carried out extensive research on intelligent manufacturing. At present, there is no unified definition of intelligent manufacturing, which involves the deep integration of each link of the manufacturing process and the generation of new information technology. The process includes an intelligent factory as the carrier, the intelligence of key manufacturing links as the core feature, and end-to-end data flow as a basis and network connections in support of its main characteristics. 
Based on the relevant research on intelligent manufacturing and the development of the domestic manufacturing industry, an intelligent manufacturing enterprise is defined in this paper as an enterprise that uses intelligent technology to produce intelligent products and that provides full life cycle services for intelligent manufacturing [22,23]. The characteristics of intelligent manufacturing enterprises are analyzed based on the following aspects:

\subsection{Technical Characteristics}

The emphasis on manufacturing technology differs from that of the traditional manufacturing enterprise. Intelligent manufacturing companies use all kinds of technology and new materials such as material manufacturing (3D printing), micro/nano technology, new energy, and digital technology (including smart technology) for product design, production, management, and service processes to realize the dynamic response of the demand and supply of iterative updates.

\subsection{Production Characteristics}

Traditional manufacturing companies pursue the standardization of production in large quantities. To meet the personalized requirements of pluralistic society consumers, intelligent manufacturing companies use internet platforms and consumer depth interactions, widely collect requirements, use large data analysis to establish production scheduling models, and use flexible production lines while maintaining scale economies to provide consumers with personalized products, thus realizing "many groups, small batch" production.

\subsection{Management Characteristics}

Different from the "bureaucratic" management mode commonly used by traditional manufacturing enterprises, intelligent manufacturing enterprises adopt the "flat" management mode. This mode takes the team as its basic unit, emphasizes internal and external coordination, and improves organizational operation efficiency. Information flow is woven into a network to adapt to a dynamic and changeable external environment and respond quickly to consumer needs.

\subsection{Organizational Characteristics}

Traditional manufacturing enterprises are production-oriented organizations, while intelligent manufacturing enterprises are learning organizations. Innovation is a basic function of such an organization. Enterprises have a strong sense of innovation and innovation capability and can continuously carry out technological innovation, organizational innovation, management innovation, and a series of innovation activities.

\section{Innovation Capability Model of Intelligent Manufacturing Enterprises}

Innovation capability was first defined by Burns and Stalker (1961) as "the ability of an enterprise to successfully adopt or implement new ideas, new processes and new products" [24]. Since then, scholars have carried out a series of studies on the innovation capabilities of an enterprise. Enterprise innovation capability was first equated with technological innovation ability, and the creation and use of new technology to create new resources became important standards with which to measure enterprise innovation ability. However, the formation and development of enterprise innovation capability are the result of multiple factors that cannot be judged by research and development ability alone. The process is also closely related to the coordination abilities of various departments of an organization, market operation abilities, and enterprise strategies.

Lall (1992) defined an enterprise's innovation capability as "the ability of an enterprise to absorb, master and improve existing technologies and innovate technologies and knowledge required by new technologies". Trott (1998) defined an enterprise's innovation capability as "the potential of an enterprise to create innovative output". Chinese scholar Wei Jiang (1995) argued that "the coupling of product innovation capability and indus- 
trial innovation capability determines the enterprise innovation capability". Guan Shixu (1999) notes that "an enterprise's innovation capability is a comprehensive reflection of its R\&D ability, marketing ability and management ability". Wang Lixin (2013) defines an enterprise's innovation capability as "a systematic capability that is closely related to an enterprise's innovation strategy and runs through the whole process of enterprise innovation".

Combined with the features of intelligent manufacturing enterprises, this paper argues that intelligent manufacturing enterprise innovation capability refers to the use of artificial intelligence, robotics, and modern information, manufacturing, and management technology while emphasizing the absorption of existing technology and promotion, upgrading existing technology and knowledge, and providing products and services to meet customer demand.

\subsection{Innovation Capability System of Intelligent Manufacturing Enterprises}

Compared to traditional manufacturing enterprises, intelligent manufacturing enterprises have obvious advantages in terms of information and intelligence, and they are also the driving force behind the innovation capability of intelligent manufacturing enterprises. The innovation capability of intelligent manufacturing enterprises mainly takes the form of "exploitation innovation" and "exploration innovation". Under the "dual drive" of informatization and intelligence, the innovation capability of intelligent manufacturing enterprises is constantly enhanced. The corresponding innovation capability system is shown in Figure 1.

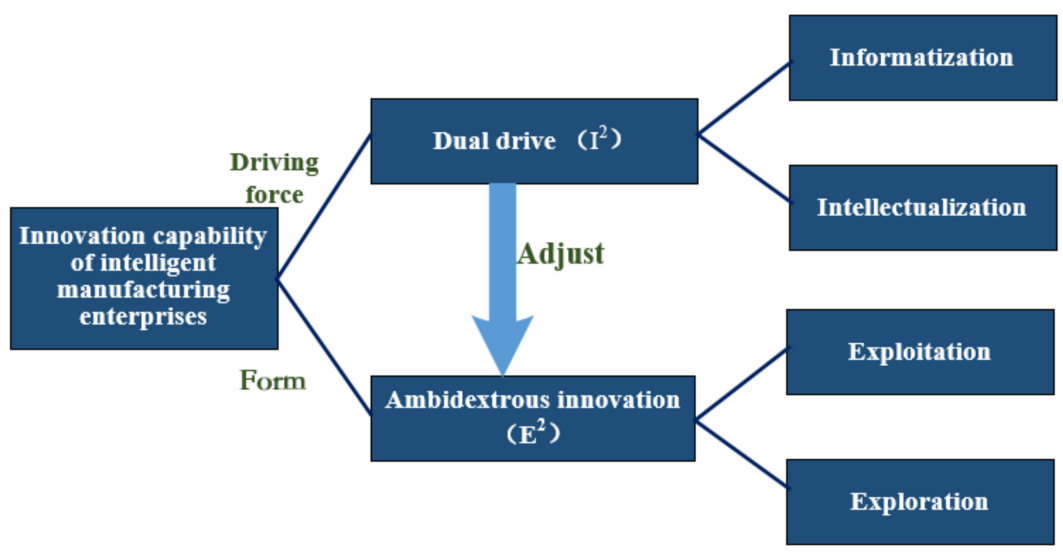

Figure 1. Innovation capability system of intelligent manufacturing enterprises.

$\mathrm{I}^{2}$ includes aspects of both "Informatization" and "Intellectualization", and Informatization is the primary stage of Intellectualization, which has both progressive and overlapping connotations. To clarify, "informationization" is defined as "data-oriented business", which involves recording the whole business process with data. Its value lies in the realization of process and rule solidification, which is convenient for large-scale unified and collaborative operations. "Intelligentization" is defined as the "intelligentization of decision-making" whereby knowledge rules are formed through value-added calculations of information, and rational decisions are made according to a changeable environment. Its value lies in automating and maximizing the matching of the supply and demand of social resources through machine self-learning.

An innovation strategy is a competitive strategy oriented toward developing new products, shortening the product life cycle, and improving the service level. The strategy emphasizes the assumption of risks, the continuous launch of new products, and the continuous improvement of service levels through two means: exploitative innovation and exploratory innovation. Enterprises often make difficult choices between "consolidating the foundation" and "seeking innovation", thus hovering between the exploitative innovation of "mining and refining existing knowledge" and exploratory innovation that involves 
"learning and mastering new knowledge" [25-27]. Exploitative innovation emphasizes the daily activities carried out by enterprises to maintain business with low risk and little room for growth; exploratory innovation is an unconventional activity carried out by enterprises to seek more room from growth. High risks and returns coexist [28].

Driven by informatization and intellectualization, enterprises are increasingly enhancing their ambidextrous innovation capabilities and their core competitiveness, which are mainly reflected in the following two aspects:

On the one hand, informatization can accurately describe customers' needs while improving the automation of business processes to meet customers' needs, which not only meets customers' needs for personalized products but also responds to the market in an agile manner. Through the use of information and collected data, intelligent data analysis platforms of enterprises, decision support systems, and data mining technology, potential customer groups are found and customer behavior patterns and in-depth business development trends are predicted, driving innovation in product design, product manufacturing, and business models $[29,30]$.

On the other hand, informatization enables the integration and synchronization of data resources and business processes, improves the efficiency of business operations, provides a management information platform from which enterprises can make decisions and manage enterprise operations, realizes the sharing and dissemination of organizational knowledge, and drives the innovation of enterprise organizational models. With the support of informatization and intellectualization, interenterprise processes are redesigned to effectively integrate related enterprise resources. Through seamless business processes used to achieve synchronous operations from product development and design to distribution and retail, business model innovation is facilitated.

\subsection{Analysis of the Mechanism of Innovation Capabilities of Intelligent Manufacturing Enterprises}

The mechanism of innovation capabilities of intelligent manufacturing enterprises can be divided into two aspects: the mechanism of a dual drive toward manufacturing and management and the mechanism of dual innovation in manufacturing and management. Under the joint action of a "dual drive" and "ambidextrous innovation", "manufacturing" and "management" enable "products" and "services" to constantly meet customers' needs and adapt to market changes. The mechanism of action is shown in Figure 2.

\subsubsection{Action Mechanism of the Effect of a "Dual Drive" on Manufacturing and Management}

Informatization is conducive to data collection such that the target value of productrelated indicators has clear target value and can be quickly transformed into production standards. Through the control and analysis of data, manufactured products can quickly respond to changes in the market and meet the needs of customers. At the same time, the controllability of manufacturing links can be realized: change controllability, abnormality controllability, inventory controllability, and defect controllability. In addition, informatization can simplify the management process, clarify the internal management of an enterprise, and improve the work efficiency of employees. Informatization also clearly shows all links of production, operation, and maintenance; promotes the efficient operation of enterprises; and then improves enterprise performance.

Intelligentization forms knowledge rules through value-added calculations of information to facilitate optimal decision-making. Intelligentization allows a production equipment control system to run reasonably under the required instructions. Only the production index needs to be controlled within the range of expected target values, and efficient, meticulous, and systematic production and manufacturing can then be carried out. This process fully guarantees the standardization and rationality of product manufacturing, makes the production process safer, increases production efficiency, and significantly improves product quality. 


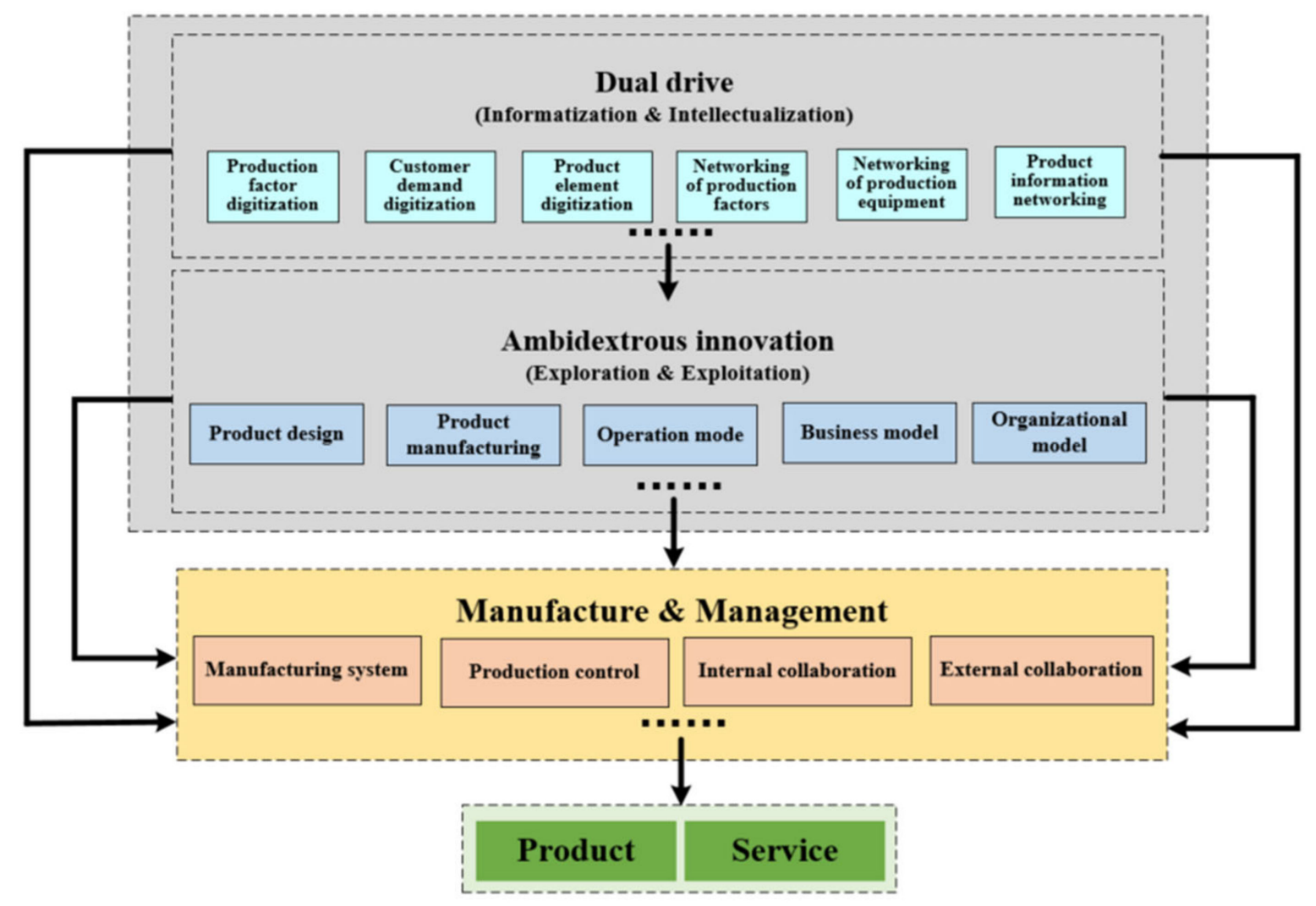

Figure 2. Action mechanism of innovation capabilities of intelligent manufacturing enterprises.

Intelligentization can realize the automatic uploading of relevant parameter information and technical information and provide automatic statistics, real-time monitoring and queries, and an effective tracking of the output and quality of terminal equipment. Intelligentization improves the automation of the data interaction process of production equipment and obtains accurate actual production data to provide meticulous and optimized data support for product production and to efficiently deal with emergencies. Intelligent manufacturing enterprises make full use of information and intelligent technology to transform existing manufacturing and management modes, improve their production efficiency, and enhance the market competitiveness of products and services.

\subsubsection{Mechanism of the Effect of Ambidextrous Innovation on Manufacturing and Management}

Driven by exploratory innovation, based on the prediction and adaptation of environmental changes, enterprises make fundamental changes to organizational processes, manufacturing processes, and methods [31,32] to survive and develop. When the external environment is relatively stable and affected by organizational inertia, most enterprises are more inclined to use exploitative innovation-by extending and enhancing existing experiences and technology - to give full play to the advantages accumulated.

Although the costs and risks of development innovation are relatively minor, an excessive emphasis on exploitation easily causes organizations to become short-sighted, miss long-term development opportunities, and ultimately be eliminated by the market [33]. Exploratory innovation can overcome the organizational rigidity caused by developmental learning and promote the further development of organizations with a more flexible and innovative new paradigm. However, exploratory learning needs to reconfigure organizational resources, which comes at a high cost and with uncertain returns [34]. Intelligent manufacturing enterprises seek a balance in time and space, use the two innovative modes 
and learn from each, encourage enterprises to allocate resources efficiently, optimize production processes, and improve organizational operation efficiency and performance [35].

\subsection{Construction of the Compound Ambidextrous Innovation Capability Model}

The high-quality functioning of informatization and intellectualization is the driving force behind the innovation abilities of intelligent manufacturing enterprises. Under the traction of market and customer demand and the "dual drive" for informatization and intellectualization, the "ambidextrous innovation" ability of intelligent manufacturing enterprises has continuously improved. A "dual drive" and "ambidextrous innovation" directly affect manufacturing and management, promote products and services, improve product quality and service levels, and comprehensively enhance the core competitiveness of intelligent manufacturing enterprises.

From the characteristics of intelligent manufacturing enterprises and the theory of ambidextrous innovation, a compound dual innovation capability model for intelligent manufacturing enterprises is constructed as shown in Figure 3.

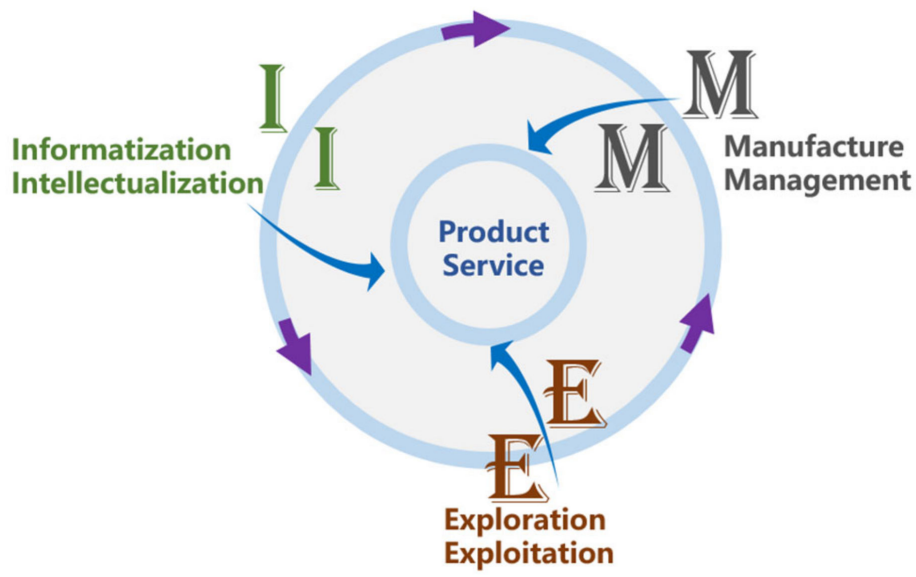

Figure 3. Compound dual innovation capability model.

\section{An Example of the Compound Dual Innovation Capability Model}

\subsection{Design Description}

There are two main viewpoints of the compound dual innovation capability model: first, under the "dual drive" of informatization and intellectualization, the "dual innovation" ability of intelligent manufacturing enterprises is constantly improving; Second, "ambidextrous innovation" forms a positive promotion of products and services, improves product quality and service level, and promotes the development of enterprises.

Therefore, the following three hypotheses are proposed to verify the correctness of the compound dual innovation capability model:

Hypothesis 1 (H1). Dual driving forces promote enterprise exploratory innovation.

Hypothesis 2 (H2). Dual driving forces promote enterprise exploitative innovation.

Hypothesis 3 (H3). Ambidextrous innovation promotes the development of enterprises.

\subsection{Data Sources}

China's Ministry of Industry and Information Technology issued a total of 304 smart manufacturing pilot demonstration projects and 194 pilot demonstration units for the integrated development of new generation information technology and manufacturing. In order to ensure the availability of data and the prominence of the characteristics of intelligent manufacturing enterprises, $44 \mathrm{~A}$-share enterprises in general equipment man- 
ufacturing, special equipment manufacturing, and electrical machinery and equipment manufacturing listed in Shenzhen and Shanghai were selected as the research objects.

All data used in this study were from corporate annual reports provided by the Shenzhen and Shanghai stock exchanges. In order to reduce the interference of outliers, this study excluded ST Company, *ST Company, and some samples with serious missing observed values of variables, ultimately obtaining 126 data pieces from 32 enterprises.

\subsection{Variable Definitions and Measure}

The variables involved in the example and their measurements are shown in Table 1.

Table 1. Variable definitions and measure.

\begin{tabular}{|c|c|c|}
\hline Variable Name & $\begin{array}{c}\text { Variables } \\
\text { Definitions }\end{array}$ & Variable Measure \\
\hline Dual driving force & $I^{2}$ & $\begin{array}{c}\text { Keywords word frequency of information and } \\
\text { informatization and intellectualization based on } \\
\text { text analysis }\end{array}$ \\
\hline Exploratory innovation & Exploration & $\begin{array}{c}\text { Annual number of invention patents granted by } \\
\text { enterprises }\end{array}$ \\
\hline Exploitative innovation & Exploitation & $\begin{array}{l}\text { Annual number of utility model patents and } \\
\text { design patents authorized by the enterprise }\end{array}$ \\
\hline Ambidextrous innovation & $E^{2}$ & $\begin{array}{c}\text { Annual number of patents granted by the } \\
\text { enterprise }\end{array}$ \\
\hline Enterprise development & Scale & Total assets (CNY 100 million) \\
\hline
\end{tabular}

\subsubsection{Dual Driving Force}

The difficulty of this study is to measure the dual driving forces of enterprises scientifically and reasonably, that is, the degree of informatization and intellectualization. Text analysis of the annual report of listed companies can effectively measure the importance an enterprise attaches to a certain strategy [36]. Certain keywords that appear more frequently in the annual report usually indicate that the enterprise has invested more attention and resources in those aspects.

Based on the existing research [37], through several rounds of consultation and discussion with expert teams from enterprises, academia, and competent government departments, this paper finally determined the keyword vocabulary of dual driving forces of enterprises, including informatization, networking, digitization, intelligence, intelligence, information technology, digital technology, Internet, Internet of things, cloud computing, big data Artificial intelligence, information resources, e-commerce, intelligent manufacturing, intelligent manufacturing, digital platform, digital transformation, ERP, information system, information technology, information management, MES, automation, robot, digital twin, digital delivery, and virtual prototype. Python language was used to analyze the text of the annual report of the research companies, and the word frequency of the keywords in the annual report is used as a proxy index to measure the dual driving force level of enterprise digital technology.

\subsubsection{Exploratory Innovation and Exploitative Innovation}

Based on the existing studies, the dual innovation level of enterprises is measured by the number of patent applications of different types [38]: the number of invention patents granted in the corresponding year is taken as the proxy variable of exploratory innovation, and the number of utility model and design patents granted is taken as the proxy variable of exploitative innovation.

\subsubsection{Enterprise Development}

The total assets of an enterprise refer to all the assets owned or controlled by an enterprise, reflecting the scale of an enterprise and serving as an important indicator to 
measure the development of an enterprise. The total assets of an enterprise are taken as a proxy variable for the development of an enterprise.

\subsection{Benchmark Estimation Model}

Due to the large dispersion of data to a certain extent, the negative binomial regression model of panel data is used for estimation. The benchmark model is set as follows:

$$
\begin{gathered}
\text { Exploration }_{i, t+1}\left(\text { Exploitation }_{i, t+1}\right)=\beta_{0}+\beta_{1} I^{2}+\varepsilon_{i, t} \\
\text { Scale }_{i, t+1}=\beta_{0}^{\prime}+\beta_{1}^{\prime} E^{2}+\varepsilon_{i, t}^{\prime}
\end{gathered}
$$

where Exploration $_{i, t+1}\left(\right.$ Exploitation $\left._{i, t+1}\right)$ is the exploratory innovation (Exploitative innovation) of enterprise $i$ in $t+1, I^{2}$ is the binary driving force of enterprise $i$ in $t$, and $\varepsilon_{i, t}$ and $\varepsilon_{i, t}^{\prime}$ is the random disturbance term.

\subsection{Result Analysis}

\subsubsection{Statistical Description}

Table 2 shows the descriptive statistics of the main variables. The standard deviation of dual driving force is 94.688 , indicating that there is a great difference between the informatization and intelligentization process of enterprises. The standard deviation of exploratory innovation and development innovation is 1407.871 and 1865.388 respectively, indicating that the innovation level of enterprises is different.

Table 2. Descriptive statistics of main variables.

\begin{tabular}{ccccccc}
\hline $\begin{array}{c}\text { Variable } \\
\text { Name }\end{array}$ & $\begin{array}{c}\text { Sample } \\
\text { Size }\end{array}$ & Minimum & Maximum & Mean & $\begin{array}{c}\text { Standard } \\
\text { Deviation }\end{array}$ & Median \\
\hline $\begin{array}{c}\text { Dual driving } \\
\text { force }\end{array}$ & 126 & 4.000 & 783.000 & 80.167 & 94.688 & 49.500 \\
$\begin{array}{c}\text { Exploration } \\
\text { Exploitation }\end{array}$ & 126 & 2.000 & 10800.000 & 458.111 & 1407.871 & 109.500 \\
$\begin{array}{c}\text { Ambidextrous } \\
\text { innovation }\end{array}$ & 126 & 0.000 & 10821.000 & 850.397 & 1865.388 & 214.500 \\
$\quad$ Scale & 126 & 4.000 & 18000.000 & 1308.508 & 3052.725 & 340.500 \\
\hline
\end{tabular}

\subsubsection{Dual Driving Force and Ambidextrous Innovation}

According to the negative binomial regression model of panel data set in Equation (1), the enterprise Exploration and Exploitation were estimated, and the results are shown in Table 3.

Table 3. Estimation results of panel data negative binomial regression model for fixed effects of binary innovation.

\begin{tabular}{ccc}
\hline & Exploration & Exploitation \\
\hline Dual driving force & $0.016^{* *}$ & $0.010^{* *}$ \\
& $(16.879)$ & $(10.323)$ \\
Likelihood ratio test & $\chi^{2}(1)=112.700$ & $\chi^{2}(1)=74.079$ \\
McFadden $\mathrm{R}^{2}$ & $p=0.000$ & $p=0.000$ \\
${ }^{*} p<0.05,{ }^{* *} p<0.01$. The $\mathrm{z}$ value is in parentheses. & 0.063 & 0.038 \\
\hline
\end{tabular}

\subsubsection{Ambidextrous Innovation and Enterprise Development}

According to the negative binomial regression model of panel data set in Equation (2), enterprise development was estimated, and the results are shown in Table 4. 
Table 4. Negative binomial regression model estimation results of panel data for fixed effects of enterprise development.

\begin{tabular}{cc}
\hline & Scale \\
\hline Ambidextrous innovation & $0.001^{* *}(22.251)$ \\
Likelihood ratio test & $\chi^{2}(1)=359.158, p=0.000$ \\
McFadden $\mathrm{R} 2$ & 0.053 \\
\hline$* p<0.05,{ }^{* *} p<0.01$. The $\mathrm{z}$ value is in parentheses. &
\end{tabular}

In conclusion, the compound dual innovation capability model has been verified.

\section{Composite Dual Innovation Capability Evaluation Index}

There are many means to evaluate the innovation abilities of enterprises, and the evaluation index system is another approach $[39,40]$. According to the compound dual innovation capability model, the innovation capabilities of intelligent manufacturing enterprises can be evaluated from three aspects of the intelligent environment: creativity and economic development centered on connotations, system composition, and mechanisms of innovation capabilities of intelligent manufacturing enterprises (see Table 5).

Table 5. Composite dual innovation capability evaluation index.

\begin{tabular}{|c|c|}
\hline First-Level Indicator & Second-Level Indicators \\
\hline \multirow{5}{*}{ Intelligent environment } & Business digitization level \\
\hline & Financial digitization level \\
\hline & Coverage rate of intelligent production system \\
\hline & Failure rate of intelligent production system \\
\hline & Enterprise network security level \\
\hline \multirow{4}{*}{ Creative ability } & Number of knowledge employees \\
\hline & Patent growth rate \\
\hline & Degree of product intelligence \\
\hline & Proportion of new product revenue \\
\hline \multirow{6}{*}{ Economic development } & Return on equity \\
\hline & Return on total assets ratio \\
\hline & Return on capital \\
\hline & Growth rate of sales profit \\
\hline & Current asset turnover \\
\hline & Inventory turnover \\
\hline
\end{tabular}

The first-level indicator "intelligent environment" mainly evaluates the innovation abilities of intelligent manufacturing enterprises based on the "dual drive" from the digitization, networking and intellectualization of business, processes, and production. The indicator includes five main second-level indicators, namely, the level of business digitization, level of financial digitization, coverage rate of the intelligent production system, failure rate of the intelligent production system, and enterprise network security level.

The first-level index "creative ability" mainly evaluates the innovation capability of intelligent manufacturing enterprises based on the notion that "knowledge creates new products". The index contains four main second-level indicators, namely, the number of knowledge employees, patent growth rate, level of product intelligence, and proportion of new product revenue.

The first-level indicator "economic development" mainly evaluates the innovation capabilities of intelligent manufacturing enterprises in terms of "capital return and efficiency". The indicator includes six main second-level indicators, including the return on 
net assets, return on total assets, return on capital, sales profit growth rate, current asset turnover level, and inventory turnover level.

\section{Conclusions}

This paper analyzes the main characteristics of intelligent manufacturing enterprises and holds that such enterprises are characterized by digitization, automation, platformization, and delayering.

On this basis, we put forward intelligent manufacturing enterprise innovation capability connotations and the structures of related systems and mechanisms, and build a "compound dual innovation" model for intelligent manufacturing enterprises. Future research can further evaluate intelligent manufacturing enterprises' innovation capability systems and their effects to illustrate the overall state of such enterprises' innovation capabilities more comprehensively and objectively propose more strategies conducive to the development of these firms.

Author Contributions: S.W. contributed to the research problem, co-collected data, and wrote the manuscript for initial submission and manuscript revision for resubmission. J.Z. designed the research framework, revised the manuscript for initial submission, and manuscript revision for resubmission. All authors have read and agreed to the published version of the manuscript.

Funding: This work was supported through Major National Social Science Foundation of China project titled Research on the strategic path and supporting system of manufacturing transformation driven by information network technology (project leader: Jinlong Zhang; NO.16ZDA013).

Institutional Review Board Statement: Not applicable.

Informed Consent Statement: Not applicable.

Data Availability Statement: Not applicable.

Conflicts of Interest: This study has no conflict of interest.

\section{References}

1. The Research Group for Research on Intelligent Manufacturing, Strategy. Research on Intelligent Manufacturing Development Strategy in China. Eng. Sci. 2018, 20, 1-8.

2. Guo, C.; Liu, S. Concept and promotion strategy of intelligent manufacturing. Sci. Technol. Rev. 2018, 36, 56-62.

3. Shan, W.; Yeming, G.; Jinlong, Z. Evaluation and development of top 100 intelligent manufacturing in china. Chin. J. Manag. 2020, 17, 159-165.

4. Jinlong, Z.; Shan, W.; Yeming, G. Research on evaluation and development of intelligent machinery manufacturing in China. China Mech. Eng. 2020, 31, 451-458.

5. Zhiming, H.; Jinlong, Z.; Huimin, M.; Jie, X.; Shuhong, Z. The policy coordination Analysis of industrial manufacturing transformation and Upgrading polices-A case study of Guangdong, Jiangsu, Hubei and Liaoning. Sci. Technol. Prog. Policy 2020, 37, 122-128.

6. Contreras, J.D.; Garcia, J.I.; Pastrana, J.D. Developing of Industry 4.0 Applications. Int. J. Online Eng. 2017, 13, 30-47. [CrossRef]

7. Binshi, X.; Dan, X.; Junyang, T.; Shiyun, D. Status and Development of Intelligent Remanufacturing in China. China Surf. Eng. 2018, 31, 1-13.

8. Li, L. China's manufacturing locus in 2025: With a comparison of "Made-in-China 2025" and "Industry 4.0". Technol. Forecast. Soc. Chang, 2018; 135, 66-74.

9. Xu, L.D.; Xu, E.L.; Li, L. Industry 4.0: State of the art and future trends. Int. J. Prod. Res. 2018, 56, 2941-2962. [CrossRef]

10. Benner, M.J.; Tushman, M.L. Exploitation, exploration, and process management: The productivity dilemma revisited. Acad. Manag. Rev. 2003, 8, 238-256. [CrossRef]

11. March, J.G. Exploration and exploitation in organizational learning. Organ. Sci. 1991, 2, 71-87. [CrossRef]

12. Fu, B.-H.; Xie, F.-J.; Han, Y.-Q. Innovation Chain Resources Integration, Ambidextrous Innovation and Innovation Performance: An Empirical Analysis Based on the New Ventures in Yangtze River Delta. China Soft Sci. 2015, 12, $176-186$.

13. Atuahene-Gima, K.; Murray, J.Y. Exploratory and exploitative learning in new product development: A social capital perspective on new technology ventures in China. J. Int. Mark. 2007, 15, 1-29. [CrossRef]

14. Guan, J.C.; Liu, N. Exploitative and exploratory innovations in knowledge network and collaboration network: A patent analysis in the technological field of nano-energy. Res. Policy 2016, 45, 97-112. [CrossRef]

15. Hui, X.; Wen, L. Empirical Study on Relationship between Organizational Learning and Ambidextrous Innovation in High-tech Enterprises. J. Manag. Sci. 2013, 26, 35-45. 
16. Xiong, L.; Xie, F.J.; Pan, Q.F. Flexible mechanism and the construction of ambidextrous innovation dynamics. Stud. Sci. Sci. 2017, 35, 940-948.

17. Ramli, N.S. Product development strategy-Innovation capacity and entrepreneurial firm performance in high-tech SMEs. Int. J. Entrep. Behav. Res. 2016, 22, 985-988. [CrossRef]

18. Jun, Z.; Qingrui, X.; Suping, Z. Research on the Conception, Structure and Measurement of the Firm's Innovation Capability: A Perspective of Management Cognition and Behavior Orientation. J. Ind. Eng. Eng. Manag. 2014, 28, 1-10.

19. Singh, A.; Li, Y.X.; Sun, Y.; Sun, Q. An Intelligent Mobile Crowdsourcing Information Notification System for Developing Countries. In Proceedings of the 1st International Conference on Machine Learning and Intelligent Communications (MLICOM). Shanghai, Peoples R China, Weihai, China, 5-6 August 2017; pp. 139-149.

20. Lin, Z.; Yang, H.; Demirkan, I. Ambidextrous culture, innovation strategy and entrepreneurial performance of high-tech firms:A knowledge flow perspective. J. Ind. Eng. Eng. Manag. 2020, 34, 30-39.

21. Simsek, Z. Organizational ambidexterity: Towards a multilevel understanding. J. Manag. Stud. 2009, 46, 597-624. [CrossRef]

22. Moreno-Luzon, M.D.; Gil-Marques, M.; Arteaga, F. Driving organizational ambidexterity through process management. The key role of cultural change. Total Qual. Manag. Bus. Excell. 2014, 25, 1026-1038. [CrossRef]

23. Wu, Y.S.; Sheng, Y.; Cai, N. Status, Timing and Path of the Residual Control Rights Succession of Family Business-A Multi-case Study Based on Haixin, TSL and Fotile. China Ind. Econ. 2016, 127-143.

24. Birkinshaw, J.; Hamel, G.; Mol, M.J. Management innovation. Acad. Manag. Rev. 2008, 33, 825-845. [CrossRef]

25. Zhuxin, Y.; Yiyuan, M. Exploratory improvisation and exploitative improvisation: A study of entrepreneurial improvisation from the perspective of amality. Nankai Bus. Rev. 2018, 21, 15-25.

26. Andriopoulos, C.; Lewis, M.W. Exploitation-Exploration Tensions and Organizational Ambidexterity: Managing Paradoxes of Innovation. Organ. Sci. 2009, 20, 696-717. [CrossRef]

27. Jansen, J.J.P.; Van Den Bosch, F.A.J.; Volberda, H.W. Exploratory innovation, exploitative innovation, and performance: Effects of organizational antecedents and environmental moderators. Manag. Sci. 2006, 52, 1661-1674. [CrossRef]

28. Tuan, L.T. Organizational Ambidexterity, Entrepreneurial Orientation, and I-deals: The Moderating Role of CSR. J. Bus. Ethics 2016, 135, 145-159. [CrossRef]

29. Romijn, H.; Albaladejo, M. Determinants of innovation capability in small electronics and software firms in southeast England. Res. Policy 2002, 31, 1053-1067. [CrossRef]

30. Qian, W.A.N.G. Research on the Mechanism and Path of IT-driven Business Model Innovation. Chin. J. Manag. 2011, 8, 126-132+150.

31. Zhang, X.T.; An, L.R. Ambidextrous innovative search, contextual separation and innovation performance. Stud. Sci. Sci. 2015, 33, 1240-1250.

32. Wang, C.L.; Rafiq, M. Ambidextrous organizational culture, contextual ambidexterity and new product innovation: A comparative study of UK and Chinese high-tech firms. Br. J. Manag. 2014, 25, 58-76. [CrossRef]

33. Clercq, D.; Thongpapanl, N.; Dimov, D. Shedding new light on the relationship between contextual ambidexterity and firm performance: An investigation of internal contingencies. Technovation 2013, 33, 119-132. [CrossRef]

34. Turner, N.; Swart, J.; Maylor, H. Mechanisms for managing ambidexterity: A review and research agenda. Int. J. Manag. Rev. 2013, 15, 317-332. [CrossRef]

35. Tian, L.F.; Zhang, G.L. The Relationship of Innovation Strategy, High-Performance Work Systems and the Performance of High Technology Firms. J. Syst. Manag. 2015, 24, 552-562.

36. Chen, S.-M.; Dai, Y.; Sheng, C. Firm responses to indigenous innovation policy in China: Symbolic or substantive? Stud. Sci. Sci. 2016, 34, 268-278.

37. Chen, Q.-J.; Wan, M.-F.; Wang, Y.-M. The Influence of Digital Technology Application on Ambidextrous Innovation of EnterprisesEmpirical Test Based on Organizational Life Cycle. Soft Sci. 2021, 31, 1-12. Available online: http:// kns.cnki.net/kcms/detail/51 .1268.G3.20210819.1205.004.html (accessed on 1 October 2021).

38. Chen, H.; Zhang, Y.; Liu, D. Government Subsidies, Tax Breaks and Enterprise's Innovation Performance: An Empirical Study on Different Life Cycle Stages. Nankai Bus. Rev. 2019, 22, 187-200.

39. Chen, Y.; Tan, C.; Yu, L. Research on evaluation index system of technological innovation ability of technology-based small and medium-sized enterprises. Sci. Technol. Prog. Policy 2012, 29, 110-112.

40. Shao, Y.; Mu, R.; Li, G. Research on the evaluation and policy of innovation ability of China's strategic emerging industries. Sci. Technol. Prog. Policy 2020, 37, 66-73. 